\title{
Tolerance of combined radiochemotherapy in cervical cancer patients
}

\author{
Barbara Izmajłowicz ${ }^{1,2, A-D}$, Małgorzata Rusiecka ${ }^{1,2, B}$, Aleksandra Sztude22, B-D , Marcin Stępieńn ${ }^{1,2, B}$, \\ Agnieszka Ignatowicz-Pacyna ${ }^{1,2, B}$, Beata Słocka-Romaniuk ${ }^{1,2, B}$, Zbigniew Mazur ${ }^{1,2, B}$, Jan Kornafel 1, 2, A, E, F \\ 1 Department of Oncology, Gynaecological Oncology Clinic, Wroclaw Medical University, Poland \\ ${ }^{2}$ Clinical Department of Gynecological Radiotherapy Lower Silesian Cancer Center, Wrocław, Poland \\ A - research concept and design; $B$ - collection and/or assembly of data; $C$ - data analysis and interpretation; \\ $D$ - writing the article; $E$ - critical revision of the article; $F$ - final approval of article
}

\author{
Address for correspondence \\ Barbara Izmajłowicz \\ E-mail: izmajlow@wp.pl \\ Funding sources \\ None declared \\ Conflict of interest \\ None declared
}

Received on December 16, 2015

Revised on January 16, 2016

Accepted on March 31, 2016

\begin{abstract}
Background. Radiochemotherapy in cervical cancer was implemented to clinical practice based on 5 randomized clinical trials, published at the end of the $20^{\text {th }}$ century, which showed improvement in the total and symptomless survivals by about $10-18 \%$. The increase of therapeutic index of such treatment can take place only when the efficiency of the treatment outweighs the increase of its toxicity. Thus, it is necessary to monitor treatment reaction during radiochemotherapy.
\end{abstract}

Objectives. The aim of this study was to assess the acute post-radiation reaction during radiochemotherapy for cervical cancer and the to analyze the reasons of the unplanned course of combined treatment.

Material and methods. A group of consecutive 176 cervical cancer patients in the clinical stage from IB to IIIB acc. to FIGO classification who underwent radiochemotherapy were taken under prospective observation in Clinical Gynecologic Radiotherapy Ward of the Lower Silesian Cancer Center in Wrocław between April 2010 and September 2012. Early post-radiation reaction was assessed in RTOG/EORTC scale once a week.

Results. During the treatment early post-radiation reaction of upper part of alimentary duct was observed in $74.4 \%$ of the patients, the reaction of lower part of gastrointestinal tract in $51.2 \%$, and in bladder $44.8 \%$. The most frequent symptoms of post-radiation reaction are: nausea $(73.3 \%$ of the patients), diarrhea (51.2\%) and vomiting (20.9\%). Leucopenia was observed in $97.1 \%$ of the patients, granulocytopenia in $70.4 \%$, anemia in $69.2 \%$, and thrombocytopenia in $25.5 \%$. The planned dose of radiotherapy was administered completely in $90.1 \%$ of the patients. A break in radiotherapy was necessary in $15.7 \%$ of the patients. In total, $44.8 \%$ of the patients did not receive radiochemotherapy according to the plan, because of the side effects of the treatment (most often leucopenia, thrombocytopenia and gastrointestinal reaction).

Conclusions. The presented data shows that radiochemotherapy causes the intensification of acute side effects of treatment and may cause unplanned course of treatment and prolongation of the total treatment time.

Key words: combined treatment, cervical carcinoma, radiochemotherapy, radiation tolerance

DOI

10.17219/acem/62454

\section{Copyright}

Copyright by Author(s)

This is an article distributed under the terms of the

Creative Commons Attribution Non-Commercial License

(http://creativecommons.org/licenses/by-nc-nd/4.0/) 
According to the Polish National Cancer Registry in 2013 there were 2,909 cases of cervical cancer and 1,669 died of this neoplasm. It is the $6^{\text {th }}$ cause of sickness in Polish women and the $7^{\text {th }}$ cause of the deaths caused by neoplasms. ${ }^{1}$ In total, in 2012 there were more than half a million of new cases worldwide. ${ }^{2}$

Radiochemotherapy in cervical cancer was implemented to clinical practice based on 5 randomized clinical trials of the third phase, published at the end of $20^{\text {th }}$ century, which showed improvement in total and symptomless survivals by about $10-18 \%$ with optimal application of combination treatment. ${ }^{3-7}$ Presently, in low stages of cervical cancer advancement (IA, IB1 i IIA1 acc. to FIGO) surgical treatment is the action of choice. In patients with risk factors found in the histopathological examination, adjuvant treatment is applied - radiotherapy or radiochemotherapy. ${ }^{8,9}$ In higher stages (IIA2- IVA) combined radiochemotherapy based on cisplatin is the action of choice. ${ }^{8-9}$

The efficiency of radiochemotherapy is based on spatial interaction, independent extermination of cancer cells, radio-sensitizing operation of some cytostatics, and also on radio-protective operation of some substances. ${ }^{10,11}$ Bentzen listed 5 main principles of operation of this treatment form - amplification of the cytotoxic effect, spatial interaction, biological cooperation, modulation in time and protection of healthy tissues. ${ }^{12}$

It should be stressed that in Poland the percent of 5-year survivals is significantly lower (54\% vs $67 \%$ ) in comparison with European data. ${ }^{2}$ Implementation of radiochemotherapy to the treatment standard of cervical cancer in 2000 has not yet caused a clear improvement in this aspect. ${ }^{13,14}$ It does not mean, however, that such improvement will not come. The increase of therapeutic index in the case of combination treatment application can take place only when the the advantages of the treatment outweigh the increase of its toxicity. Thus, it is necessary to monitor treatment reaction during radiochemotherapy. It seems very probable, however, that the reason for lower than expected efficiency of radiochemotherapy in our country results from disturbances in the planned course of treatment caused by acute reactions appearing during the therapy. The present analysis is based on the experience of the former Clinical Gynecologic Radiotherapy Ward of the Lower Silesian Cancer Center in Wrocław, Poland.

\section{Material and methods}

The aim of this study was to assess the degree of the intensity of acute post-radiation reaction during radiochemotherapy on a malignant cervical cancer and the analysis of the reasons for the course of treatment, which is discordant to the accepted plan of treatment.

A group of consecutive 176 cervical cancer patients in the clinical advancement from IB to IIIB acc. to FIGO classification who underwent radiochemotherapy were taken under prospective observation at former Clinical Gynecologic Radiotherapy Ward of the Lower Silesian Cancer Center in Wrocław between April 2010 and September 2012. Four patients did not complete the combined treatment ( 2 because their cancer spreading, 1 because of acute renal failure, 1 because of myocardial infarction) and were excluded from statistical analysis which was run for 172 patients.

The age ranged from 29 to 76 years (average -53.8 years). The characteristics of the material is contained in Table 1. In 33 patients (19.2\%) radiochemotherapy was applied as a complimentary treatment after a surgery and in $139(80.8 \%)$ as an independent treatment of radical assumption.

In the examined patients teletherapy and brachytherapy were applied. Teletherapy was planned based on computer tomography. GTV, CTV, PTV area and critical organs (bladder, rectum, intestines, femoral heads) were indicated. Radiation with external beams concerned the pelvis area (neoplastic infiltration and pelvis lymph glands) in all patients, and in 14 patients $(8.1 \%)$ it was the area of paraaortic lymph glands. One hundred twenty-four patients (72.1\%) were radiated using a classic conformal technique (3D), and 48 patients (27.9\%) using dynamic techniques, 11 patients (6.4\%) using IMRT technique, and 37 (21.5\%) RAPID ARC arch. The choice of the technique was related to their different availability in the center in different time. The total doses planned to the pelvis area were: in 170 patients (98.8\%) 50.4Gy in 28 fractions, in 1 patient

Table 1. Characteristics of the patients in the aspect of clinical advancement according to FIGO class., histopathological type and the degree of histological malignancy

\begin{tabular}{|c|c|c|c|}
\hline \multicolumn{2}{|c|}{ Parameter } & $\begin{array}{l}\text { Number of } \\
\text { patients (n) }\end{array}$ & $\begin{array}{c}\text { Percent } \\
\text { share (\%) }\end{array}$ \\
\hline \multirow{4}{*}{$\begin{array}{l}\text { Degree of cinical } \\
\text { advancement } \\
\text { according to FIGO }\end{array}$} & । & 36 & 20.9 \\
\hline & $\|$ & 73 & 42.4 \\
\hline & $\| \mathrm{II}$ & 4 & 2.3 \\
\hline & $\| I \mathrm{~B}$ & 59 & 34.3 \\
\hline \multirow{3}{*}{$\begin{array}{l}\text { Histopatological } \\
\text { type }\end{array}$} & $\begin{array}{l}\text { squamous cel } \\
\text { carcinoma }\end{array}$ & 160 & 93 \\
\hline & adenocarcinoma & 8 & 4.7 \\
\hline & Other & 4 & 2.3 \\
\hline \multirow{4}{*}{$\begin{array}{l}\text { Degree of } \\
\text { histopatological } \\
\text { malignancy }\end{array}$} & G1 & 8 & 4.7 \\
\hline & G2 & 44 & 25.6 \\
\hline & G3 & 25 & 14.5 \\
\hline & not defined & 95 & 55.2 \\
\hline
\end{tabular}


45Gy in 25 fraction and in one patient $59.4 \mathrm{~Gy}$ in 33 fractions, and for the area of paraortic lymph gland 45Gy in 25 fractions. External radiation was performed once a day, 5 times a week with $\mathrm{X}$ photons with the energy of 10-18 $\mathrm{MeV}$, on the accelerator of CLINAC type. HDR brachytherapy using Irydium192 was applied in 170 patients (98.8\%). Brachytherapy was introduced on various stages of the treatment depending on anatomical conditions, and the doses varied from 15 to 36 Gy in $2-6$ fractions. Systemic treatment was run using cisplastin administered intravenously in 7 day intervals in the dose of $40 \mathrm{mg} / \mathrm{m}^{2}$ p.c. starting from the first day of radiotherapy. The treatment plan had 5-6 courses of chemotherapy.

Early post-radiation reaction was assessed in all the patients in RTOG/EORTC scale according to the prepared card of post-radiation reaction (Fig.1) once a week. The reaction from the bladder, upper and lower part of alimentary tract, intensity of nausea, vomiting and diarrhea and hematological reaction within 3 cell lines - leukocyte, erythrocyte, and megakaryocyte - was assessed. Hematological parameters were always assessed a day before and the day after the subsequent chemotherapy cycle and individually according to the indications.

Average values $(\mathrm{x})$, median $(\mathrm{M})$, scope (min-max), bottom and top quartile (25Q-75Q) and standard deviation (SD) of continuous parameters were calculated for all the groups. The obtained data underwent statistical analysis in which the test $X^{2}$ with Yates' adjustment, Fisher test and Pearson's or Spearman's $r$ correlation coefficient were used. The verification of the hypothesis on equality of the average of the tests was run using ANOVA variance analysis or Kruskal-Wallis sum test. Statistical analysis was performed using a computer packet of statistical programs EPIINFO v. 7.1.1 (from 2-07-2013).

\section{Results}

During the treatment, early post-radiation reaction of upper part of alimentary duct was observed in 128 patients $(74.4 \%)$, the reaction of lower part of gastrointestinal tract in 88 patients $(51.2 \%)$, and in bladder in 77 patients $(44.8 \%)$. The most frequent symptoms of post-radiation reaction are: nausea (126 patients, $73.3 \%$ examined), diarrhea (88 patients, 51.2\%) and vomiting (36 patients, 20.9\%). Detailed data concerning the intensity of post-radiation reaction in alimentary duct and bladder is presented in Table 2.

During radiochemotherapy, hematological changes were observed in 170 from 172 patients (98.8\%). In 97.1\% of the patients leucopenia was observed, in $70.4 \%$ granulocytopenia, in $69.2 \%$ anemia, and in $25.5 \%$ thrombocytopenia. Disorders within two cell lines were observed in 88 patients $(51.2 \%)$ : in $6(3.5 \%)$ patients they concerned white blood cell and megakaryocyte line, in 82 (47.7\%) white blood cell and red blood cell line, and within all
Table 2 . Degree of intensity of the early post-radiation reaction in gastrointestinal tract and bladder in RTOG/ EORTC scale

\begin{tabular}{|c|c|c|c|}
\hline $\begin{array}{l}\text { Location of } \\
\text { the reaction }\end{array}$ & $\begin{array}{l}\text { Degree of } \\
\text { the reaction } \\
\text { intensity } \\
\text { according to } \\
\text { RTOG/EORTC }\end{array}$ & $\begin{array}{l}\text { Number of } \\
\text { patients }(n)\end{array}$ & $\begin{array}{c}\text { Percent share } \\
(\%)\end{array}$ \\
\hline \multirow{5}{*}{$\begin{array}{l}\text { Upper part of } \\
\text { gastroin- } \\
\text { testinal tract }\end{array}$} & G0 & 44 & 25.6 \\
\hline & G1 & 32 & 18.6 \\
\hline & $\mathrm{G} 2$ & 94 & 54.7 \\
\hline & G3 & 2 & 1.2 \\
\hline & G4 & 0 & 0 \\
\hline \multirow{5}{*}{$\begin{array}{l}\text { Lower part of } \\
\text { gastroin- } \\
\text { testinal tract }\end{array}$} & G0 & 84 & 48.8 \\
\hline & G1 & 5 & 2.9 \\
\hline & $\mathrm{G} 2$ & 74 & 43 \\
\hline & G3 & 8 & 4.7 \\
\hline & G4 & 1 & 0.6 \\
\hline \multirow{5}{*}{ Bladder } & G0 & 95 & 55.2 \\
\hline & G1 & 8 & 4.7 \\
\hline & G2 & 69 & 40.1 \\
\hline & G3 & 0 & 0 \\
\hline & G4 & 0 & 0 \\
\hline \multirow{5}{*}{ Nausea } & G0 & 46 & 26.7 \\
\hline & G1 & 78 & 45.3 \\
\hline & $\mathrm{G} 2$ & 32 & 18.6 \\
\hline & G3 & 16 & 9.3 \\
\hline & G4 & 0 & 0 \\
\hline \multirow{5}{*}{ Vomits } & G0 & 136 & 79.1 \\
\hline & G1 & 21 & 12.2 \\
\hline & $\mathrm{G} 2$ & 15 & 8.7 \\
\hline & G3 & 0 & 0 \\
\hline & G4 & 0 & 0 \\
\hline \multirow{5}{*}{ Diarrhea } & G0 & 84 & 48.8 \\
\hline & G1 & 63 & 36.6 \\
\hline & $\mathrm{G} 2$ & 22 & 12.8 \\
\hline & G3 & 2 & 1.2 \\
\hline & G4 & 1 & 0.6 \\
\hline
\end{tabular}


3 lines they were noticed in 35 (20.3\%) patients. Detailed data related to post-radiation reaction from the side of bone marrow is presented in Table 3.

The relationship between the intensity of selected parameters of post-radiation reaction and radiochemotherapy performed after surgical treatment (adjuvant

Table 3. Degree of intensity of early post-radiation reaction from bone marrow side in RTOG/ EORTC scale

\begin{tabular}{|c|c|c|c|}
\hline $\begin{array}{l}\text { Parameter of } \\
\text { reaction }\end{array}$ & $\begin{array}{l}\text { Degree of } \\
\text { intensity of } \\
\text { the reaction } \\
\text { according to } \\
\text { RTOG/EORTC }\end{array}$ & $\begin{array}{l}\text { Number of } \\
\text { patients (n) }\end{array}$ & $\begin{array}{c}\text { Percent share } \\
(\%)\end{array}$ \\
\hline \multirow{5}{*}{$\begin{array}{l}\text { WBC } \\
\text { (leukocytes) }\end{array}$} & G0 & 5 & 2.9 \\
\hline & G1 & 19 & 11 \\
\hline & G2 & 86 & 50 \\
\hline & G3 & 61 & 35.5 \\
\hline & G4 & 1 & 0.6 \\
\hline \multirow{5}{*}{$\begin{array}{l}\text { GRAN } \\
\text { (granulocytes) }\end{array}$} & G0 & 51 & 29.7 \\
\hline & G1 & 39 & 22.7 \\
\hline & $\mathrm{G} 2$ & 57 & 33.1 \\
\hline & G3 & 23 & 13.4 \\
\hline & G4 & 2 & 1.2 \\
\hline \multirow{5}{*}{$\begin{array}{l}\text { PLT } \\
\text { (platelets) }\end{array}$} & G0 & 128 & 74.4 \\
\hline & G1 & 27 & 15.7 \\
\hline & $\mathrm{G} 2$ & 14 & 8.1 \\
\hline & G3 & 3 & 1.7 \\
\hline & G4 & 0 & 0 \\
\hline \multirow{5}{*}{$\begin{array}{l}\text { HGB } \\
\text { (hemoglobin) }\end{array}$} & G0 & 53 & 30.8 \\
\hline & G1 & 92 & 53.5 \\
\hline & G2 & 27 & 15.7 \\
\hline & G3 & 0 & 0 \\
\hline & G4 & 0 & 0 \\
\hline \multirow{5}{*}{$\begin{array}{l}\mathrm{HCT} \\
\text { (hematocrit) }\end{array}$} & G0 & 66 & 38.4 \\
\hline & G1 & 71 & 41.3 \\
\hline & $\mathrm{G} 2$ & 9 & 5.2 \\
\hline & G3 & 26 & 15.1 \\
\hline & G4 & 0 & 0 \\
\hline
\end{tabular}

radiochemotherapy), radiation of the paraaortic lymph glands and the applied teletherapy technique (3D technique, IMRT technique, RapidArc technique) was analyzed. The analysis showed a statistically significant ( $\mathrm{p}=0.00317$ ) dependence of the diarrhea intensity on adjuvant radiochemotherapy and a statistically significant ( $\mathrm{p}=0.0221)$ dependence of vomiting intensity on paraortic lymph glands radiation. Among patients radiated using dynamic techniques, the post-radiation reaction of the gastrointestinal tract and bladder was observed more seldomly than in patients radiated using a classic conformal 3D technique, but the difference was not statistically significant (Table 4).

Intensification of post-radiation reaction in a statistical significant or close to statistically significant degree correlated with a break in radiotherapy (lower part of gastrointestinal tract $\mathrm{p}=0.0177$, vomiting $\mathrm{p}=0.0208$, diarrhea $\mathrm{p}=0.00461$, granulocytopenia $\mathrm{p}=0.0114$, thrombocytopenia $\mathrm{p}=0.00000$, anemia $\mathrm{p}=0.00550$, leukopenia $\mathrm{p}=0.0795)$. Statistically significant dependence of breaks in irradiation, adjuvant radiochemotherapy, radiation of paraortic lymph glands and kind of teletherapy technique was not observed.

The influence of the patients' age on the radiochemotherapy tolerance was also observed. It did not influence the frequency of radiochemotherapy breaks, but together with the increase dose and the number of administered chemotherapy courses distinctly decreased (relatively $\mathrm{p}=0.014$ and $\mathrm{p}=0.0508$ ). Only the intensification of post-radiation reaction from the lower gastrointestinal tract and diarrhea were statistically positively significant in correlation with age (relatively $\mathrm{p}=0.0120, \mathrm{r}=0.19$ and $p=0.0150, r=0.19)$. No relationships between other parameters of post-radiation reaction and the patients' age were observed.

In 155 patients (90.1\%) the planned dose of radiotherapy was administered completely. Minimal administered dose of teletherapy was $43.2 \mathrm{~Gy} / 24$ fractions, maximal $57.6 \mathrm{~Gy} / 32$ fractions, average dose was $50.3 \mathrm{~Gy}$, and the modal one $50.4 \mathrm{~Gy}$.

In 9 patients $(5.4 \%)$ the undesirable effects of radiation resulted in the administration of lower doses than planned earlier - in 7 patients (4.2\%) leucopenia, in $3(1.8 \%)$ trombocytopenia, in $3(1.8 \%)$ diarrhea, in $1(0.6 \%)$ intestinal obstruction. Increasing the dose of radiation resulted among others from an interval in radiotherapy (6 patients) and from the necessity of using boost (1 patient). A break in radiotherapy was necessary in $27(15.7 \%)$ patients. The most frequent reasons were: leukopenia (16 patients, 9.3\%), trombocytopenia (12 patients $7 \%$ ), diarrhea (7 patients, $4.1 \%$ ), anemia (4 patients, $2.3 \%$ ), infection of lower air ducts (2 patients, $1.2 \%$ ). In individual patients the reasons for the break were the following: pulmonary embolism, hemorrhage cervix cancer requiring surgical intervention, hemorrhage from gastrointestinal tract and appendicitis. In 11 pa- 
Table 4. Intensity of post radiation reaction depending on the radiotherapy technique

\begin{tabular}{|c|c|c|c|c|c|c|c|c|c|}
\hline \multicolumn{5}{|c|}{$3 \mathrm{D} n=124(\%)$} & \multicolumn{5}{|c|}{ DYN n $=48(\%)$} \\
\hline 0 & 1 & 2 & 3 & 4 & 0 & 1 & 2 & 3 & 4 \\
\hline
\end{tabular}

\begin{tabular}{|c|c|c|c|c|c|c|c|c|c|c|c|}
\hline Reaction bladder & 50.8 & 4.8 & 44.4 & 0 & 0 & 66.7 & 4.1 & 29.2 & 0 & 0 & 0.165 \\
\hline $\begin{array}{l}\text { Reaction gastrtointestinal } \\
\text { tract upper }\end{array}$ & 23.4 & 17.7 & 57.3 & 1.6 & 0 & 31.3 & 20.8 & 47.9 & 0 & 0 & 0.505 \\
\hline $\begin{array}{l}\text { Reaction gastrointestinal } \\
\text { tract lower }\end{array}$ & 44.4 & 4.0 & 47.6 & 4.0 & 0 & 60.4 & 0 & 33.3 & 6.3 & 0 & 0.125 \\
\hline Nausea & 25.0 & 44.4 & 19.4 & 11.3 & 0 & 31.3 & 47.9 & 16.7 & 4.2 & 0 & 0.453 \\
\hline Vomits & 77.4 & 13.7 & 8.9 & 0 & 0 & 83.3 & 8.3 & 8.3 & 0 & 0 & 0.611 \\
\hline Diarrhea & 44.4 & 40.3 & 12.9 & 1.6 & 0.8 & 60.4 & 27.1 & 12.5 & 0 & 0 & 0.325 \\
\hline WBC & 3.2 & 12.9 & 46.0 & 37.1 & 0.8 & 2.1 & 6.3 & 60.4 & 31.3 & 0 & 0.447 \\
\hline GRAN & 31.4 & 19.4 & 35.5 & 12.9 & 0.8 & 25.0 & 31.3 & 27.1 & 14.6 & 2.1 & 0.414 \\
\hline PLT & 75.8 & 16.1 & 6.5 & 1.6 & 0 & 70.8 & 14.6 & 12.5 & 2.1 & 0 & 0.622 \\
\hline HGB & 31.5 & 51.6 & 16.9 & 0 & 0 & 29.2 & 58.3 & 12.5 & 0 & 0 & 0.676 \\
\hline HT & 39.5 & 37.1 & 5.6 & 17.7 & 0 & 35.4 & 52.1 & 4.2 & 8.3 & 0 & 0.240 \\
\hline
\end{tabular}

tients $(6.6 \%)$ more than one reason of the interval occurred, including 5 patients $(2.9 \%)$ with pancytopenia. Minimal time of the interruption was 2 days and maximal 21, an average time of the break was 9.56 days, the median equals 10 days, (SD 4.44). Seven-days interval or a shorter one was taken in $8(4.6 \%)$ patients and the one longer than 7 days in 19 (11\%) of the examined patients.

During the combined treatment 5-6 cisplastin courses were planned. One chemotherapy course was administered to 5 patients (2.9\%), 2 courses in 4 (2.3\%), 3 courses in 10 (5.8\%), 4 courses in 40 (23.3\%), 5 courses in 98 (57\%) and 6 courses in 15 (8.7\%). The average administered dose of cytostatic was $309.3 \mathrm{mg}$. Leukopenia, thrombocytopenia, anemia, reaction of alimentary duct and also the symptoms of renal failure, infection of lower pulmonary system, no consent to continue chemotherapy, pulmonary occlusion, hypersensitive reaction to cisplastin were related to the decrease of the number of chemotherapy courses. The influence of the intensity of diarrhea on the administered number of chemotherapy courses $(\mathrm{p}=0.0852)$ was close to being statistically significant.
In 14 patients $(8.1 \%)$ the interval in radiotherapy was related to the decrease of the number of chemotherapy courses, in 2 patients $(1.2 \%)$ decrease of the radiotherapy dose and the number of chemotherapy took place, in 1 patient $(0.6 \%)$ decrease of the dose and an interval in radiotherapy occurred. In total, 77 patients (44.8\%) did not receive radiochemotherapy in accordance with the assumed plan, because of the side effects of the treatment (most often it was leucopenia, thrombocytopenia and gastrointestinal reaction). Hematological reaction dominated among the reasons of diminishing the dose of chemotherapy and radiotherapy and additional intervals during radiotherapy. The reasons were presented in details in Table 5 .
Table 5. The reasons of radiotherapy course inconsistent with the plan

\begin{tabular}{|l|c|c|c|c|c|c|}
\hline \multirow{2}{*}{ Reasons } & \multicolumn{2}{|c|}{$\begin{array}{c}\text { Diminishing the dose of } \\
\text { radiotherapy }\end{array}$} & \multicolumn{2}{|c|}{ Interval in radiotherapy } & \multicolumn{2}{|c|}{$\begin{array}{c}\text { Diminishing the number } \\
\text { of chemotherapy courses }\end{array}$} \\
\cline { 2 - 8 } & $\mathrm{n}$ & $\%$ & $\mathrm{n}$ & $\%$ & $\mathrm{n}$ & $\%$ \\
\hline Leukopenia & 7 & 4.1 & 16 & 9.3 & 37 & 21.5 \\
\hline Thrombocytopenia & 3 & 1.7 & 12 & 7 & 9 & 5.2 \\
\hline Anemia & 0 & 0 & 4 & 2.3 & 4 & 2.3 \\
\hline Pancytopenia & 0 & 0 & 5 & 2.9 & 0 & 0 \\
\hline Diarrhea & 3 & 1.7 & 6 & 3.5 & 5 & 2.9 \\
\hline Other & 1 & 0.6 & 6 & 3.5 & 8 & 4.7 \\
\hline
\end{tabular}


Table 6. Post-radiation reactions in alimentary duct and urinal tract during radiotherapy

\begin{tabular}{|c|c|c|c|c|c|c|c|c|c|c|}
\hline Reactionzyn & G & $\begin{array}{l}\text { SWOG } \\
87-97\end{array}$ & GOG 123 & GOG 85 & GOG 120 & $\begin{array}{l}\text { Pearcey } \\
\text { et al. }\end{array}$ & Lukka et al. & $\begin{array}{l}\text { Kirwan } \\
\text { et al. }\end{array}$ & $\begin{array}{l}\text { Kumaran } \\
\text { et al. }\end{array}$ & Results \\
\hline \multirow{4}{*}{$\begin{array}{l}\text { Alimentary } \\
\text { ductarmowy }\end{array}$} & 1 & \multirow{2}{*}{$\begin{array}{l}\text { not } \\
\text { reported }\end{array}$} & \multirow{2}{*}{$\begin{array}{l}\text { not } \\
\text { reported }\end{array}$} & \multirow{2}{*}{$\begin{array}{l}\text { not } \\
\text { reported }\end{array}$} & \multirow{2}{*}{$\begin{array}{c}\text { not } \\
\text { reported }\end{array}$} & \multirow{2}{*}{$\begin{array}{c}\text { not } \\
\text { reported }\end{array}$} & \multirow{4}{*}{ 9-15\% } & \multirow{2}{*}{$17.5 \%$} & \multirow{4}{*}{$\begin{array}{c}\text { not } \\
\text { reported }\end{array}$} & $73 \%$ \\
\hline & 2 & & & & & & & & & $45.9 \%$ \\
\hline & 3 & \multirow{2}{*}{$17 \%$} & \multirow{2}{*}{$14 \%$} & \multirow{2}{*}{$24 \%$} & \multirow{2}{*}{$15-43 \%$} & \multirow{2}{*}{$40 \%$} & & \multirow{2}{*}{$1.5 \%$} & & $1.5 \%$ \\
\hline & 4 & & & & & & & & & $1.2 \%$ \\
\hline \multirow{4}{*}{ Diarrhea } & 1 & \multirow{4}{*}{$\begin{array}{l}\text { not } \\
\text { reported }\end{array}$} & \multirow{4}{*}{$\begin{array}{l}\text { not } \\
\text { reported }\end{array}$} & \multirow{4}{*}{$\begin{array}{l}\text { not } \\
\text { reported }\end{array}$} & \multirow{4}{*}{$\begin{array}{c}\text { not } \\
\text { reported }\end{array}$} & \multirow{4}{*}{$\begin{array}{l}\text { not } \\
\text { reported }\end{array}$} & \multirow{4}{*}{$\begin{array}{l}\text { not } \\
\text { reported }\end{array}$} & \multirow{4}{*}{$\begin{array}{c}\text { not } \\
\text { reported }\end{array}$} & $54.4 \%$ & $36.3 \%$ \\
\hline & 2 & & & & & & & & $20.3 \%$ & $12.8 \%$ \\
\hline & 3 & & & & & & & & $15.2 \%$ & $1.2 \%$ \\
\hline & 4 & & & & & & & & $1.2 \%$ & $0.6 \%$ \\
\hline \multirow{4}{*}{ Vomits } & 1 & \multirow{4}{*}{$\begin{array}{l}\text { not } \\
\text { reported }\end{array}$} & \multirow{4}{*}{$\begin{array}{l}\text { not } \\
\text { reported }\end{array}$} & \multirow{4}{*}{$\begin{array}{l}\text { not } \\
\text { reported }\end{array}$} & \multirow{4}{*}{$\begin{array}{l}\text { not } \\
\text { reported }\end{array}$} & \multirow{4}{*}{$\begin{array}{l}\text { not } \\
\text { reported }\end{array}$} & \multirow{4}{*}{$\begin{array}{l}\text { not } \\
\text { reported }\end{array}$} & \multirow{4}{*}{$\begin{array}{l}\text { not } \\
\text { reported }\end{array}$} & $73.4 \%$ & $12.2 \%$ \\
\hline & 2 & & & & & & & & $19 \%$ & $8.7 \%$ \\
\hline & 3 & & & & & & & & 0 & 0 \\
\hline & 4 & & & & & & & & 0 & 0 \\
\hline \multirow{4}{*}{ Urinary tract } & 1 & \multirow{4}{*}{$\begin{array}{l}\text { not } \\
\text { reported }\end{array}$} & \multirow{4}{*}{$\begin{array}{l}\text { not } \\
\text { reported }\end{array}$} & \multirow{4}{*}{$\begin{array}{l}\text { not } \\
\text { reported }\end{array}$} & & & & & & \\
\hline & 2 & & & & not & not & 80 & 40 & not & $44.0 \%$ \\
\hline & 3 & & & & reported & reported & $1-070$ & & reported & \\
\hline & 4 & & & & & & & $0 \%$ & & 0 \\
\hline
\end{tabular}

\section{Discussion of results}

Randomized clinical tests showing higher efficiency of radiotherapy related to the simultaneous application of systemic treatment mentioned at the beginning only partly touched the problem of post-radiation reactions. ${ }^{3-7}$ Meta-analyses published later confirmed the results showing the improvement of total survivals by $10-12 \%$ and symptomless survivals by $13-16 \% \cdot{ }^{15-19}$ It is estimated that before publishing these results radiochemotherapy was applied in less than $30 \%$ of the patients, and after 1999 this number increased to over $60 \%{ }^{20}$ The improvement of survivals in the groups with radiochemotherapy was related to the intensification of post-radiation reactions from gastrointestinal and urinary tracts and especially to hematological reaction. ${ }^{3-7,15-19,21}$ Detailed data related to post-radiation reactions in the research mentioned above, meta-analyses and their comparison to own results are presented in Tables 6 and 7.

The radiotherapy technique may be significant to the frequency and intensity of post-radiation reactions. In conformal techniques, especially in IMRT and RapidArc techniques, the volume of radiated critical organs (small intestine, large intestine, bladder, bone marrow) compared to the conventional technique decreases by $10-60 \% .{ }^{22-24}$ Reports related to post-radiation reactions depending on the radiation technique are contradictory. Gandhi et al. proved that in patients who undergo radiochemotherapy using the conventional technique, the post-radiation reaction in gastrtointestinal tract in the $\mathrm{G}$ $\geq 2$ degree was present in $63.6 \%$ of the patients and in the IMRT technique in $31.8 \%$ the patients, the reaction in $\mathrm{G} \geq 3$ degree respectively in $27.3 \%$ and $4.5 \%$ pts. ${ }^{25}$ Hui et al. proved that for the bone marrow the values V10, $20,30,40,50,30,40,50$ are more advantageous in IMRT technique compared to $3 \mathrm{D}$ technique, which is also related to the decrease of hematological complications. ${ }^{26}$ Similarly, Simpson et al. proved such a dependency for the volume of intestine receiving the dose above 45Gy and the intensification of post radiation reaction. ${ }^{27}$ Erpolat et al. proved, however, that post-radiation reaction in $\mathrm{G} \geq 2$ degree in 3D technique compared with IMRT technique related to anemia was present respectively in $2 \%$ and $27 \%$ of the patients, as for leukopenia respectively in $41.5 \%$ and $53 \%$, as for neutropenia respectively in $12 \%$ and $24.5 \%$ of the patients and as for thrombocytopenia respectively in 0 and $4.5 \%$. The values of V10, 20, 30, 40 were better in IMRT technique, but they did not relate to the diminished post-radiation reactions. ${ }^{28}$ In the group tested by us the patients were radiated using 3D conformal technique, dynamic techniques - IMRT or RapidArc. Dosimetric analysis of the dependency of radiated volume of critical organs, doses and intensity of post-radiation reaction was not carried out. The post-radiation reaction from gastrointestinal tract and urinary bladder was present more rarely in patients radiated using $d y-$ namic techniques than 3D technique, but this difference was not statistically significant. 
Table 7. Hematological complications during radiochemotherapy

\begin{tabular}{|c|c|c|c|c|c|c|c|c|c|c|}
\hline & & $\begin{array}{l}\text { SWOG } \\
87-97\end{array}$ & GOG 123 & GOG 85 & GOG 120 & $\begin{array}{l}\text { Pearcey } \\
\text { et al. }\end{array}$ & Lukka et al. & $\begin{array}{c}\text { Kirwan } \\
\text { et al. }\end{array}$ & $\begin{array}{l}\text { Kumaran } \\
\text { et al. }\end{array}$ & $\begin{array}{l}\text { Own } \\
\text { results }\end{array}$ \\
\hline \multirow{2}{*}{ Hematological } & $\begin{array}{l}1 \\
2\end{array}$ & $\begin{array}{l}\text { not } \\
\text { reported }\end{array}$ & $\begin{array}{c}\text { not } \\
\text { reported }\end{array}$ & $\begin{array}{l}\text { not } \\
\text { reported }\end{array}$ & $\begin{array}{c}\text { not } \\
\text { reported }\end{array}$ & $\begin{array}{c}\text { not } \\
\text { reported }\end{array}$ & \multirow{2}{*}{$18-47 \%$} & \multirow{2}{*}{$\begin{array}{l}\text { not } \\
\text { reported }\end{array}$} & \multirow{2}{*}{$\begin{array}{c}\text { not } \\
\text { reported }\end{array}$} & $54.6 \%$ \\
\hline & $\begin{array}{l}3 \\
4\end{array}$ & $17 \%$ & $21 \%$ & $24 \%$ & $27-46 \%$ & $40 \%$ & & & & $44.2 \%$ \\
\hline \multirow{3}{*}{ Leukocyty } & 1 & \multirow{3}{*}{$\begin{array}{c}\text { not } \\
\text { reported }\end{array}$} & \multirow{3}{*}{$\begin{array}{c}\text { not } \\
\text { reported }\end{array}$} & \multirow{3}{*}{$\begin{array}{c}\text { not } \\
\text { reported }\end{array}$} & \multirow{3}{*}{$\begin{array}{l}\text { not } \\
\text { reported }\end{array}$} & \multirow{3}{*}{$\begin{array}{l}\text { not } \\
\text { reported }\end{array}$} & \multirow{3}{*}{$\begin{array}{c}\text { not } \\
\text { reported }\end{array}$} & \multirow{2}{*}{$49.4 \%$} & \multirow{3}{*}{$\begin{array}{c}\text { not } \\
\text { reported }\end{array}$} & \multirow{2}{*}{$61 \%$} \\
\hline & $\begin{array}{l}2 \\
3\end{array}$ & & & & & & & & & \\
\hline & 4 & & & & & & & $16.4 \%$ & & $36 \%$ \\
\hline \multirow{3}{*}{ Hemoglobin } & 1 & \multirow{3}{*}{$\begin{array}{c}\text { not } \\
\text { reported }\end{array}$} & \multirow{3}{*}{$\begin{array}{l}\text { not } \\
\text { reported }\end{array}$} & \multirow{3}{*}{$\begin{array}{c}\text { not } \\
\text { reported }\end{array}$} & \multirow{3}{*}{$\begin{array}{l}\text { not } \\
\text { reported }\end{array}$} & \multirow{3}{*}{$\begin{array}{l}\text { not } \\
\text { reported }\end{array}$} & \multirow{3}{*}{$\begin{array}{c}\text { not } \\
\text { reported }\end{array}$} & \multirow{2}{*}{$39.3 \%$} & \multirow{3}{*}{$\begin{array}{c}\text { not } \\
\text { reported }\end{array}$} & \multirow{2}{*}{$69.2 \%$} \\
\hline & $\begin{array}{l}2 \\
3\end{array}$ & & & & & & & & & \\
\hline & 4 & & & & & & & $0.5 \%$ & & $0 \%$ \\
\hline \multirow{4}{*}{ Platelets } & 1 & \multirow{4}{*}{$\begin{array}{c}\text { not } \\
\text { reported }\end{array}$} & \multirow{4}{*}{$\begin{array}{l}\text { not } \\
\text { reported }\end{array}$} & \multirow{4}{*}{$\begin{array}{c}\text { not } \\
\text { reported }\end{array}$} & \multirow{4}{*}{$\begin{array}{l}\text { not } \\
\text { reported }\end{array}$} & \multirow{4}{*}{$\begin{array}{l}\text { not } \\
\text { reported }\end{array}$} & & & & \\
\hline & 2 & & & & & & not & & not & $25.0 \%$ \\
\hline & 3 & & & & & & reported & $170 \%$ & reported & 17\% \\
\hline & 4 & & & & & & & $1.7 \%$ & & $1.7 \%$ \\
\hline
\end{tabular}

The presented data suggests that radiochemotherapy causes the intensification of acute side effects of the treatment and may prolong the total treatment period, which would not be advantageous. It is assumed that the total time of radiotherapy in cervical cancer patients should not exceed 8 weeks. ${ }^{29-31}$ Prolongation of the total treatment time over 55-60 days causes a decrease of the local cure and distant survivals by $1 \%$ for each day over 55-60 days. ${ }^{31}$ In the groups of patients who underwent radiochemotherapy the treatment time ranges from 35 to 92 days (average time 51- 52 days). ${ }^{32,33}$ Some researchers point out, however, that prolongation of radiochemotherapy duration, contrary to the prolongation of independent radiotherapy, does not influence the treatment results (recurrence in the radiated area, DFS, OS). ${ }^{32}$ Discontinuous radiation during radiochemotherapy takes place in $3-20 \%$ of the patients. ${ }^{33-35}$ In the present study the interval took place in $15.7 \%$ of the patients, which is within the ranges quoted above.

The difference concerns the number of courses of chemotherapy. According to the literature, $70-92 \%$ of the patients receive the planned number; in the present study 5 courses of DDP were received by $65.7 \%$ of the patients, which can be crucial for the efficiency of the treatment, since receiving fewer than 5 chemotherapy courses is related with a worse prognosis for the patients. ${ }^{33-36}$

According to the literature the age and undergone surgery do not influence the planned course of radiochemotherapy. ${ }^{34,35}$ Similarly, in our own research the surgery and age did not influence the interval in radiotherapy, although the age influenced the number of chemotherapy courses.

According to the data from the literature and our own research, hematological complications and ones related to gastrointestinal tract are the most often reasons for the treatment course not going according to the primary plan. ${ }^{34,35}$ Special attention should be paid to the hemoglobin level during radiochemotherapy. The hemoglobin level $>10 \mathrm{mg} \%$ before and during radiotherapy and nadir during radiotherapy is an independent prognostic and predictive factor, as it influences the longer total survivals, and the value of hemoglobin in the last 2 weeks of treatment has special meaning. ${ }^{37-41}$ In the present study anemia was present in about $70 \%$ of the patients (stage G1 and 2).

According to Jakubowicz, about $78 \%$ of cervix cancer patients receive the whole treatment; in the present study the amount of patients were at a much lower percent $-65.2 \%{ }^{42}$ This fact can be very significant in evaluating reason for the significant difference between the treatment of cervix cancer in Poland and in Europe, as it can be assumed that Wrocław center does not differ much in this aspect from other centers in the country. The low percent of patients receiving the whole planned treatment, prolongation of the total therapy time and decreasing the number of chemotherapy courses undoubtedly influence negatively the survivals of patients. The assessment of survivals, however, was not the subject of the present study. 


\section{References}

1. Wojciechowska U, Didkowska J. Zachorowania i zgony na nowotwory złośliwe w Polsce. Krajowy Rejestr Nowotworów, Centrum Onkologii - Instytut im. Marii Skłodowskiej-Curie. Available from: http://onkologia.org.pl/raporty/, accessed on 06.12.2015

2. Ferlay J, Soerjomataram I, Ervik M, Dikshit R, Eser S, Mathers C, Rebelo M, Parkin DM, Forman D, Bray F. GLOBOCAN 2012 v1.0, Cancer Incidence and Mortality Worldwide: IARC CancerBase No. 11 [Internet]. Lyon, France: International Agency for Research on Cancer; 2013. Available from: http://globocan.iarc.fr, accessed on 11.12.2015

3. Peters W, Liu P, Barrett R, et al. Concurrent chemotherapy and pelvic radiation therapy compared with pelvic radiation therapy alone as adjuvant therapy after radical surgery in high-risk early-stage cancer of the cervix. J Clin Oncol. 2000;18:1606-1613.

4. Keys $H$, Bundy B, Stehman F, et al. Cisplatin, radiation, and adjuvant hysterectomy compared with radiation and adjuvant hysterectomy for bulky lb cervical carcinoma. N Engl J Med. 1999;340:1154-1167.

5. Whitney C, Sause W, Bundy B, et al. Randomized comparison of fluorouracil plus cisplatin versus hydroxyurea as an adjunct to radiation therapy in stage IIB-IVA carcinoma of the cervix with negative para-aortic lymph nodes: a Gynecologic Oncology Group and Southwest Oncology Group Study. J Clin Oncol. 1999;17:1339-1348.

6. Rose $P$, Bundy B, Watkins $E$, et al. Concurrent cisplatin- based radiotherapy and chemiotherapy for locally advanced cervical cancer. N Engl J Med. 1999;340:1144-1153.

7. Morris M, Eifle $\mathrm{P}, \mathrm{Lu}$ J, et al. Pelvic radiation with concurrent chemotherapy compared with pelvic and para-aortic radiation for high risk cervical cancer. N Engl J Med. 1999;340:1137-1143.

8. NCCN, National Comprehensive Cancer Network, Practice Guidelines in Oncology-V. I. 2016: http://www. nccn.org/proffesionals/physicians.

9. Krzakowski M., Warzocha K. Zalecenia postępowania diagnostyczno-terapeutycznego w nowotworach złośliwych 2013 rok. Via Medica Gdańsk, 2013.

10. Jassem J. Postępy w skojarzonym leczeniu nowotworów z udziałem radioterapii i chemioterapii. Nowotwory. 2000;50:12-20.

11. Steel GG. Basic Clinical Radiobiology. Arnold, London, 2002.

12. Bentzen SM, Harari PM, Bernier J. Exploitable mechanisms for combining drugs with radiation: Concepts, achievements and future directions. Nat Clin Pract Oncol. 2007;4:172-180.

13. Błaszczyk J, Jagas M, Bębenek M. Przeżycia 5-letnie chorych na nowotwory złośliwe $z$ lat 1985-2004 w woj. Dolnośląskim. Dolnośląski Rejestr Nowotworów, Wrocław 2011.

14. Wojciechowska U, Didkowska J, Zatoński W. Pięcioletnie przeżycia chorych na nowotwory złośliwe w Polsce. Nowotwory. 2010;60:122-129.

15. Green J, Kirwan J, Tierney J, et al. Survival and recurrence after concomitant chemotherapy and radiotherapy for cancer of the uterine cervix: A systematic review and meta-analysis. Lancet. 2001;358:781-786.

16. Green J, Kirwan J, Tierney J, et al. Concomitant chemotherapy and radiotion therapy for cancer of the uterine cervix. Cohrance Database Syst Rev. 2005;20:3.

17. Lukka $\mathrm{H}$, Hirte $\mathrm{H}$, Fyles $\mathrm{A}$, et al. Concurrent cisplatin-based chemotherapy plus radiotherapy for cervical cancer- a meta-analysis. Clin Oncol. 2002;14:203-212.

18. Kirwan J, Symonds P, Green, J, et al. A systematic review of acute and late toxicity of concomitant chemoradiation for cervical cancer. Radiother Oncol. 2003;68:217-226.

19. Kumaran A, Guruvare S, Sharan K, et al. Chemoradiation related acute morbidity in carcinoma cervix and correlation with hematologic toxicity: A South Indian prospective study. Asian Pac J Cancer Prev. 2014;15(11):4483-4486.

20. Eifel PJ. Chemoradiotherapy in the treatment of cervical cancer, Semin Radiat Oncol. 2006;16:177.

21. Pearcey $R$, Brundage $M$, Drouin $P$, et al. Phase III trial comparing radical radiotherapy with and without cisplatin chemotherapy in patients with advanced squamous cell cancer of the cervix. J Clin Oncol. 2002;20:966.

22. Van de Bunt $L$, van der Heide U, Ketelaars M, et al. Conventional, conformal, and intensity-modulated radiation therapy treatment planning of external beam radiotherapy for cervical cancer: The impact of tumor regression. Int J Radiat Oncol Biol Phys. 2006;64:189-196.
23. Bednaruk-Młyński E, Senkus-Konefka E, Górzyński M, et al. Paraleloposed fields vs. four fields, and two-(2D) vs. three-dimensional (3D) radiotherapy planning in thin patients with gynecological malignancies. Reports of practical oncology and radiotherapy. 2003;8(supl 2):242.

24. Heron D, Gerszten K, Selvaraj R, et al. Conventional 3D versus intensity modulated radiotherapy for the adjuvant treatment of gynecologic malignancies: A comparative dosimetric study of dose-volume histograms small star, filled. Gynecol Oncol. 2003;91:39-45.

25. Gandhi AK, Sharma DN, Rath GK, et al. Early clinical outcomes and toxicity of intensity modulated versus conventional pelvic radiation therapy for locally advanced cervix carcinoma: A prospective randomized study. Int J Radiat Oncol Biol Phys. 2013;87:542-548.

26. Hui B, Zhang Y, Shi F, et al. Association between bone morrow dosimetric parameters and acute hematologic toxicity in cervical cancer patients undergoing concurrent chemoradiotherapy: Comparison of tree- dimensional conformal radiotherapy and intensity- modulated radiation therapy. Int J Gynecol Cancer. 2014;24:1648-1652.

27. Simpson DR, Song WY, Moiseenko V, et al. Normal tissue complication probability analysis of acute gastrointestinal toxicity in cervical cancer patients undergoing intensity modulated radiation therapy and concurrent cisplatin. Int J Radiat Oncol Biol Phys. 2012;83:81-86.

28. Erpolat OP, Alco G, Caglar HB, et al. Comparison of hematologic toxicity between 3DCRT and IMRT planning in cervical cancer patients after concurrent chemoradiotherapy: A national multicenter study. Eur J Gynaecol Oncol. 2014;35:62-66.

29. Nag S, Erickson B, Thomadsen B, et al. The American Brachyterapy Society Recommendation for High Dose Rate Brachyterapy for carcinoma of the cervix. Int J Radiat Oncol Biol Phys. 2000;48:201.

30. Perez CA, Grigsby PW, Castro-Vita H, et al. Carcinoma of the uterine cervix. Impact of prolongation of overall treatment time and timing of brachyterapy on outcome of radiation therapy. Int J Radiat Oncol Biol Phys. 1995;32:1275.

31. Petereit DG, Sarkaria JN, Hartmann TJ, et al. Adverse effect of treatment prolongation in cervical carcinoma. Int J Radiat Oncol Biol Phys. 1995;32:1301.

32. Shaverdian N, Gondi V, Sklenar KL, et al. Effects of treatment duration during concomitant chemoradiation therapy for cervical cancer. Int J Radiat Oncol Biol Phys. 2013;86:562-568.

33. Toita T, Kitagawa R, Hamano T, et al. Feasibility and acute toxicity of concurrent chemoradiotherapy (CCRT) with high- dose rate intracavitary brachytherapy (HDR- ICBT) and 40-mg $/ \mathrm{m}^{2}$ weekly cisplatin for Japanese patients with cervical cancer: Results of a multi- institutional phase 2 study (JGOG 1066). Int J Gynecol Cancer. 2012;22:1420-1426.

34. Tan LT, Russell S, Burgess L. Acute toxicity of chemo-radiotherapy for cervical cancer: The Addenbrooke's experience. Clin Oncol. 2004; 16:255-260.

35. Krusun S, Pesee M, Supakalin N, et al. Treatment interruption during concurrent chemoradiotherapy of uterine cervical cancer; analysis of factors and outcomes. Asian Pac J Cancer Prev. 2014;15:5653-5657.

36. Nugent EK, Case AS, Hoff JT, et al. Chemoradiation in locally advanced cervical carcinoma: An analysis of cisplatin dosing and other clinical prognostic factors. Gynecol Oncol. 2010;116:438-441.

37. Winter WE, Maxwell GL, Tian C, et al. Association of hemoglobin level with survival in cervical carcinoma patients treated with concurrent cisplatin and radiotherapy: A Gynecologic Oncology Group Study. Gynecol Oncol. 2004;94:495.

38. Choi YS, Yi CM, Sin Jl, et al. Impact of hemoglobin on survival cervical carcinoma patients treated with concurrent chemoradiotherapy is dependent on lymph node metastasis findings by magnetic resonance imaging. Int J Gynecol Cancer. 2006;16:1846

39. Ferrandina $G$, Distefano $M$, Smaniotto $D$, et al. Anemia in patients with advanced cervical carcinoma administered preoperative radiochemotherapy: association with pathological response to treatment and clinical outcome. Gynecol Oncol. 2006;103:500

40. Grogan M, Thomas GM, Melamed I, et al. The importance of hemoglobin levels during radiotherapy for carcinoma of the cervix. Cancer. 1999;86:1528.

41. Thomas G. The effect of hemoglobin level on radiotherapy outcomes: The Canadian experience. Semin Oncol. 2001;28:60.

42. Jakubowicz J, Blecharz P, Skotnicki P, et al. Toxicity of concurrent chemoradiotherapy for locally advanced cervical cancer. Eur J Gynaecol Oncol. 2014;35:393-399. 